\title{
"Blood Is a Very Special Juice"*: Racialized Bodies and Citizenship in Twentieth-Century Germany
}

\author{
Fatima El-TAYEB
}

The 1999 plan of the Social Democratic government to adjust Germany's I9I3 nationality law has generated an intensely emotional debate. In an unprecedented action, the opposition Christian Democrats managed to gather hundreds of thousands of signatures against the adjustment that would have granted citizenship to second generation "immigrants" born in Germany. ${ }^{1}$ At the end of the twentieth century, Germans still strongly cling to the principle of jus sanguinis. The idea that nationality is not connected to place of birth or culture but rather to a "national essence" that is somehow incorporated in the subject's blood has been strong in Germany since the early nineteenth century and has been especially decisive for the country's twentieth-century history.

The myth of blood has intertwined with that of "race"; both imply the heredity of mental traits that connect people otherwise not related. Images of race belong to the West's "deep structure", voiced in different manners and to different degrees in different political systems and times, but always there. ${ }^{2}$ The conjuncture of "race" and "blood" therefore, has proven resistant to political changes. Germany, with its national identity that through almost the whole of the twentieth century and four political systems has been explicitly based on "blood", is a case in point. ${ }^{3}$

This article explores the roots of the German self-definition in larger Western concepts of identity that are deeply racialized and often manifested through gendered constructions relating to sexuality. Legal exclusion generated by those concepts centered on "race" rather than other possible forms of distinction. German blood implicitly meant "white blood", be it in the

\section{* Johann Wolfgang von Goethe, Faust I (1808), verse 1740.}

I. The 1913 law grants the right of naturalization to "ethnic Germans", who have lived outside of Germany for generations, while "ethnic foreigners", who have lived within Germany for generations, are denied the same right. Thereby, an evergrowing number of "cultural Germans" is created, who are treated as foreigners solely because they miss the qualification of "German blood". See Rogers Brubaker, Citizenship and Nationhood in France and Germany (Cambridge, MA, 1992).

The Christian Democrats' action had no direct political consequences since German law does not allow plebiscites on national issues. Nevertheless it has proven decisive, because the government was forced to compromise after losing the majority in the Bundesrat (representing the German states) in elections that centered on the issue of nationality.

2. See e.g. David T. Goldberg, Racist Culture. Philosophy and the Politics of Meaning (Cambridge, MA, 1993).

3. For the post-World-War-II-period, this article concentrates on the federal republic, the political system transferred to the reunified Germany. 
imperial Germany of the I9Ios or the federal republic of the 1960s. Accordingly, in this century public and scientific discourses around national identity often centered on relationships between white Germans and blacks as representatives of the most "foreign blood" and on the danger of the latter entering and tainting the "German blood". This thinking caused racist exclusions in systems that did not consider themselves based on racial thinking. ${ }^{4}$

Changes in the political climate had little influence on the attitudes towards interracial relationships, but it did make a difference whether they involved black men and white women or white men and black women. Race and gender appear as interdependent factors, with class being a less significant independent variable in the construction of national identity.

\section{RACE, SEX, AND SCIENCE}

With the rise of the Enlightenment in seventeenth-century Europe came a shift from "faith" to "knowledge". Christianity lost its position as sole and unchallenged ideology and the world was no longer divided between the faithful and the unbelieving, but rather between man as rational, responsible being and man as savage. The construction of the white man as the embodiment of all the qualities of civilization and rationality necessarily needed a counterpart that lacked all these qualities and continually confirmed the white race's superiority. The "black race" was systematically built up as this counterpart. This is not to deny that in Europe, men defined women as other before the idea of races even existed. But the hierarchy of races was central to the construction of a modern Western identity that needed to distance itself both from the rest of the world and its own medieval self. Modern Western gender identity therefore was not about being male or female, but about being white and male or female.

The alleged connection of physical and mental "racial qualities" immediately gave the concept of races an ideological function; it never was a neutral description of biological facts. Instead it worked to stabilize the new bourgeois order by replacing the aristocracy of "blue blood" with that of "white blood", creating new bonds and loyalties. Meanwhile it justified slavery and colonialism, since the creation of a natural order that granted full humanity only to whites meant that mechanisms of exploitation and oppression unacceptable among them could be labeled "civilizing mission" when directed against other "races": "The races are not meant to play the same role in history, and the lower races have to serve the uses of the higher ones. The uses of the higher ones are the 'aims of humanity', because only they

4. The period of National Socialism with its explicit connection of nationality and race will therefore not be considered here. 
represent the highest form of intellectual human power." Divided into numerous small states, Germany played little part in the slave trade and early colonialism, but its intellectuals were crucial to establishing the new world order that constructed the "savage native" as fundamentally and inherently different. ${ }^{6}$ This might be connected to the country's particular geographical position. Placed in the center of Europe, it had always known a mixture of cultures, flows of immigration and emigration. Lacking a national structure, there was little apart from language that connected the regions that were later to form Germany. The invention of a national myth accordingly did not concentrate on an actually shared cultural and political history, but on an idealized German "spirit", passed on not by nationality or culture but by blood.? Since the myth of the "white race" was created on quite similar terms, the concepts intertwined, defining Germans through their position as "crown of the white race".

Following Darwin's theory of evolution, in the late nineteenth century the "science of races" aimed at developing a method that paralleled the growing disciplines of natural, "exact" sciences. Its proponents tried to discover the "natural laws" that governed humans and human society, creating a model of the world that had race - and nothing else - at its core. All over Europe and the United States, men trained in such disciplines as biology, zoology, history, and above all medicine, turned their attention to race as the last answer to all human questions. ${ }^{8}$ Race had always determined the course of history and continued to do so in the present. The antagonisms of gender and class were secondary compared to this, in fact, they had to be overcome in order to strengthen Europe for the great eternal war between the races. ${ }^{9}$ The problem faced by black men and women - that whatever they did they could never be anything but "other", simply because they were not white - took different forms for oppressed groups within white society. But their otherness was not absolute: they were "normal" instead of

5. Ludwig Woltmann, "Die Klassen- und Rassentheorie in der Soziologie", in PolitischAnthropologische Revue, (1905/6), p. 424. All translations by the author.

6. See e.g. Immanuel Kant, Von den verschiedenen Rassen der Menschen (1775) and Johann Friedrich Blumenbach, De generis humanis varietate nativa (1795).

7. For details on the construction of the German national myth see Helga Schultz, "Mythos und Aufklärung: Frühformen des Nationalismus in Deutschland”, Historische Zeitschrift, 236 (1996), pp. 31-6r.

8. For the influence racist Social Darwinism gained in the West, see e.g. Michael Banton and Jonathan Harwood, The Race Concept (London 1975), p. 42; George L. Mosse, Towards the Final Solution. A History of European Racism (New York 1978) and David T. Goldberg, Racist Culture. 9. While being extremely hostile towards all ideologies that denied the central position of race, some Social Darwinists nevertheless attempted to develop a "Germanic" socialism. They could identify with socialist concepts as long as they were applied only within the "white race" and believed that the white working class incorporated more of the race's "true qualities" than the decadent and weakly middle and upper classes. See e.g. Ludwig Woltmann, Die Darwinsche Theorie und der Sozialismus (Düsseldorf, 1899). 
"other" in interracial relations, where "white" remained monolithic in spite of actual divisions. White women were considered inferior by white men, as were workers by the bourgeoisie, but non-white people were required to see all whites as superior to them. There was no such requirement for white women where black men were concerned or for white workers regarding a non-white middle class. To save civilization and humanity, after all, the superior, but comparatively few, "pure whites" had to stick together and keep the inferior masses subjected.

Historians often assume that Germans did not participate in the movement of scientific racism, at least where it was concerned with the "black race", that anti-Semitism was somehow Germany's "substitute" to the racism prevailing in other countries. ${ }^{\text {10 }}$ Actually, the German school of "social anthropology" was among the leading in the world and its major journal basically focused on three subjects: northern Europeans and particularly Germans as the "true whites" and therefore perfect humans; the black race as the eternally most primitive variety of humanity; and racial mixing as the source of all social problems and "re-aryanisation", i.e. restrictive population politics, as their solution. ${ }^{11}$ Before World War I, much less attention was paid to Germany's Jewish minority; afterwards though, the racism of the social anthropological press became distinctively and aggressively antiSemitic.

Historians, national economists and anthropologists considered the race scientists' ideas on the white and yellow race oversimplified and extreme. ${ }^{12}$ Academia did not doubt, however, that "race" was a useful category in analyzing historical and social processes and concerning their attitude towards the black race, the Social Darwinists were rather mainstream. That Africans constituted the most primitive kind of humanity, separated from the civilized Europeans by a wide biological gap, was a notion that had been well established by the early twentieth century. ${ }^{13}$ Even critics of the

Io. See e.g. Banton/Harwood, The Race Concept, p. 42; Reiner Pommerin, "Sterilisierung der Rheinlandbastarde': Das Schicksal einer farbigen deutschen Minderheit 1918-1937 (Düsseldorf 1979), p. 1I, and H. Friedlander, The Origins of Nazi Genocide: from Euthanasia to the Final Solution (Chapel Hill, NC, 1995).

II. See Politisch-Anthropologische Revue (PAR), founded in I9or by Ludwig Woltmann, published until 1914 and then continued under the name of Politisch-Antropologische Monatszeitschrift.

12. Criticism was provoked by the race scientists' division of the "white race" into northern, southern and eastern Europeans, leaving the "Nordics" as the only "true whites", while east Europeans were supposedly "tainted" by Asian and south Europeans by black and Semitic blood, and by the assumption that Asia never produced an autochtonous civilization (i.e. one that was not created by "Aryan invaders"). See a.o. Erwin Baur et al., Grundriss der menschlichen Erblichkeitslehre und Rassenhygiene (Munich, 1923), pp. 413-415.

13. Nothing was more damaging here, probably, than Georg Wilhelm Friedrich Hegel's judgment of Africa as "the continent without history". In effect it placed Africans outside the realm of humanity but nevertheless for almost two centuries was not really taken into question; Vorlesungen über die Philosophie der Geschichte (Stuttgart, 1945), p. I44. 
racist ideology merely insisted that blacks could reach the intellectual level of the other races if removed to the right surroundings. ${ }^{\text {I4 }}$

Since the academic world was exceptionally united in its judgment of the black race, society was likely to accept it. Accordingly, the race scientists' obsession with the dangers of racial mixing became common wisdom: miscegenation could only lead to degeneration of the superior white race. This extremely negative attitude logically sprang from the assumption of a strict racial hierarchy. Nothing threatened the "natural order" more than a blurring of the supposedly clear boundaries between the races: the existence of people with a mixed heritage undermined the dogma of the different races being clearly separable and actually mutually exclusive. Accordingly, "mixing" between the black and white race was condemned as "unnatural" and disastrous not only for the offspring itself but for all mankind. Both Social Darwinists and the general public believed that "bastards" were stale, inherited only the negative qualities of their "parent-races" and had such an uneven psychic constitution that they were naturally driven to crime and mental distortions: "The often physically and mentally extremely disgusting products of such relationships tend to combine the drawbacks, weaknesses and mistakes of both races, of the strength of the white father and the beauty of the colored mothers those split-births usually inherit nothing. ${ }^{\text {ns }}$ "Mixed blood" as the ultimate threat to the West meant miscegenation as the ultimate sin. More than any other form of interaction, society outlawed sexual contact between the races. At the same time, all other racial stereotypes were dwarfed by the West's obsession with black sexuality. In fact, this obsession became constitutive for the discourse on sexuality itself.

Retrospectively, the race scientists seem like reactionary fanatics, but they saw themselves - and were seen - as taking part in the pioneering process of substituting fiction with fact, establishing truly objective methods and founding modern Western science. They shared this belief with disciplines such as eugenics and sexual sciences. All these "modern sciences" were based on the idea that the human body, if only scrutinized and categorized neatly enough, was the key to all secrets of human nature. Replacing charity and social politics with the "natural laws" of the body, these Social Darwinists argued, would automatically create the perfect sociery. A "natural" elimination of the "inferior" and ruling of the "fittest" would reverse the current "degeneration", i.e. the "deviant" dominating the "normal". Race as well as sexuality were key words in this process.

Sexuality was at the very center of the modern civil society; it was, after all, the antidote to civilization. It was nature in its purest form, "the wild animal" in all of us, the one thing that could break down the control of the

14. See e.g. Friedrich Hertz, Rasse und Kultur (Leipzig, 1915), p. I50.

15. Friedrich Richter, Zeitschrift fuer Kolonialpolitik, Kolonialrecht und Kolonialwirtschaft, 7 (1905), p. 664 . 
mind over the body and thus of civilization over nature. In this, it recalled another discourse, as Ann Laura Stoler analyzed for the nineteenth century:

The nineteenth-century discourse on bourgeois sexuality may better be understood as a recuperation of a protracted discourse on race, for the discourse on sexuality contains many of the latter's most salient elements. That discourse on sexuality was binary and contrastive, in its nineteenth-century variant always pitting that middle-class respectable sexuality as a defense against an internal and external other that was at once essentially different but uncomfortably the same. The contaminating and contagious tropes of nineteenth-century sexual discourse were not new: they recalled and recuperated a discourse that riveted on defensive techniques for constant purification'. ${ }^{16}$

Only whites were believed to be able to domesticate their sexual instincts and thereby to create order from chaos. But whereas all other races were viewed as lacking in this respect, blacks were associated with sexual aggression. Similarly "black blood" was seen as especially aggressive in polluting the white race: one drop was enough. As with all the other determinants of modernity, the normalization of sexuality began with a dualistic division. Whites were rational, moral and controlled, whereas blacks were emotional, amoral and driven by their instincts. Only after this division was established and white superiority again confirmed, was the white population itself categorized according to this standard, finally leaving as completely normal only the white, heterosexual, middle-class male. All those who were not, e.g. prostitutes and homosexuals, and often the working class as whole, were deviant exactly for the same reason that blacks in general were. Those groups were not only believed to have the mental, but also the physical characteristics of the "primitive races". At the same time, such "deviations" as prostitution and homosexuality were considered dominant practices within African societies, and blacks were believed to be "natural" members of the working class. ${ }^{17}$

Through this binary division, blacks gained a high symbolic value for a European bourgeoisie that was in the process of defining itself: anti-civilizatory forces were symbolized by unrestrained sexuality and unrestrained sexuality was symbolized by blacks. As this derived from a projection of both Western fears and desires, it resulted in a complex, at times contradictory construction. Dominant however, was the image of Africans in their "natural state", designing to males and females alike an overpowering sexual drive and identifying the threatening, uncivilized, "dark" field of sexuality with the threatening, uncivilized, "dark continent" of Africa. Of course, the reduction of blacks to their alleged sexual nature

16. Ann Laura Stoler, Race and the Education of Desire: Foucaut's History of Sexuality and the Colonial Order of Things (Durham, NC, 1995), p. 193.

17. See e.g. Max Dessoir, "Zur Psychologie der Vita Sexualis", Allgemeine Zeitschrift fur Psychiatrie und psychologisch-gerichtliche Medizin, (1893), p. 142. 
had consequences for their perception in terms of gender. Black men were not "real men", since they missed the intellectual and moral qualities that justified male dominance, but at the same time, they symbolized the essence of maleness, an excess of "normal" male sexual aggression. This aggression was assumed to be directed against whites. There was an almost automatic reference to black men's "natural" drive to rape white women, whenever white oppression needed to be portrayed as mere self-defense.

Control over the white female body was a privilege of rational man and a necessity. Only he could protect her from the black beast. White man's control of the black female body on the other hand, was central to both slavery and colonialism. Literal control in form of rape left no "safe space" and penetrated every aspect of the subjected's life, asserting power over black women and men. Metaphorical control completely objectified the black woman, turning her into the absolute other and the victim into the perpetrator:

Images of Black [...] women in "heat" versus "frigid" White women mythically elide the history of subordination of Third World women by First World men. The hot/frigid dichotomy implies three interdependent axioms within the sexual politics of colonialist discourse: first, the sexual interaction of Black [...] men and White women can only involve rape (since white women cannot possibly desire Black [...] men); second, the sexual interaction of White men and Black [...] women cannot involve rape (since Black [...] women are in perpetual heat and desire the White master); and third, the interaction of Black [...] men and Black [...] women also cannot involve rape, since both are in perpetual heat. ${ }^{18}$

Scientific analyses of black sexuality focused overwhelmingly on women. ${ }^{19}$ In the course of the nineteenth century, black female sexuality came to be viewed as inherently pathological in opposition to the virtuous and passive nature of white women. This not only justified white men's sexual violence against black women, but also their oppression of white women. To keep society in balance and check the potentially subversive force of sexuality, male aggression had to be counterbalanced by female passivity - and not only where sex was concerned. In the white mind, black women not only violated the gender code, but their behavior, deemed pathological, deprived them of male protection. What this meant for her position in a racist society was made quite clear within colonial Germany.

\section{IMPERIAL GERMANY AND THE "OTHER"}

Since German colonial activities lasted only from 1884 to 1914 , they are often neglected as irrelevant to both the German society and colonial history

I8. Ella Shohat/Robert Stam (eds), Untbinking Eurocentrism: Multiculturalism and the Media (London, 1994), p. 157.

19. See Arthur Brittan and Mary Maynard, Sexism, Racism, and Oppression (Oxford, 1984); Paula Giddings, "The Last Taboo", in Toni Morrison (ed.), Race-ing Justice, En-Gendering Power (New 
in general..$^{20}$ This perception requires correction. German colonialism put the race theories already dominating the public mind into practice on a broad scale. This did not only change the colonized countries but also the colonizer. A movement of "colonial enthusiasm", massive government propaganda supported by the country's strong nationalist groups, buttressed the acquirement of overseas territories. Aiming at presenting colonialism as necessary for Germany's survival as one of the world's "leading nations", it readily deployed Social Darwinist theories. ${ }^{21}$ Exhibitions of "natives" in zoos, "scientific studies" distributed freely to schools, and the widely popular colonial novels popularized the racial theories that had already conquered academia. ${ }^{22}$ The idea of a necessary domination of Germans over peoples too primitive to govern themselves quickly became commonly accepted. The Social Democrats (SPD), while criticizing colonial "excesses", agreed in principle, even though "colonial enthusiasm" aimed at alienating workers from the increasingly influential SPD by presenting it as "unpatriotic" and "anti-colonialist". ${ }^{23}$ Unemployed, i.e. potentially dangerous, members of the working class were supposed to find a new home in the safely removed colonies. According to the Social Darwinist framework, race solidarity would replace class antagonism as whites of all classes were presented with a people that could be formed into a dependent and racially-separated working class. A popular colonial writer stated:

In the context of world history, only the necessity to give up their free national barbarism and to become a class of servants to the whites gives the natives the right to exist. As for individuals, so it is for peoples that the useless have no right to live and that an existence is the more useful the more important it is for the general development. ${ }^{24}$

York, 1992), pp. 441-470, and Sander L. Gilman, Sexuality: An Illustrated History (New York, 1989).

20. The German colonies were Togo, Cameroon, "German Southwest Africa", "German East Africa" and parts of New Guinea, Samoa and the Solomon Islands.

2I. There were numerous personal and ideological correspondences between the race scientists and the nationalist organizations, mainly the German Colonial Society (Deutsche Kolonialgesellschaft) and the Pangerman League (Alldeutscher Verband). The colonial department of the Ministry of Foreign Affairs, in its turn, relied heavily on the expertise of both the colonial society and individual race scientists. See: Bundesarchiv Berlin (BAB), R Ioor Reichskolonialamt, Bd. 5418 , "Rechtsfragen bei Mischehen und Mischlingen".

22. See Sybille Benninghoff-Lühl, Deutsche Kolonialromane 1884-1914 in inrem Entstehungs- und Wirkungszusammenhang (Bremen, 1983). The country's most popular teenage novel, selling half a million copies up to 1918, was Gustav Frensen's Peter Moors Fahrt nach Südwest (1906), describing the colonial war in Southwest Africa.

23. See: Gustav Noske, Kolonialpolitik und Sozialdemokratie (Stuttgart, 1914), p. 56. The international socialist congresses of Amsterdam, 1904, and Stuttgart, 1907, also principally supported colonialism (ibid., p. 223).

24. Paul Rohrbach, Deutsche Kolonialwirtschaft (Berlin, 1909), p. 17. Rohrbach, a colonial inspector who published several "scientific" books on life in Southwest Africa, became the "voice" of German settlers. 
The truth of these Social Darwinist beliefs remained unquestioned. Accordingly, the German self-image underwent a crisis when the Herero and Nama in the biggest colony, "German Southwest Africa" (now Namibia), began a revolt in 1904 that, despite using an unheard number of soldiers and amount of money, could not be suppressed until 1907. The German response led to a genocide leaving only one-quarter of the Herero alive. The commander of the German troops justified this extermination by claiming the revolt as "the beginning of a race war" ${ }^{25}$ After they regained power, the Germans established a system of control and oppression that was unique in the world and later became model for the South African apartheid system. ${ }^{26}$ It included the destruction of the traditional community and family structures, complete expropriation, mass deportations, and passes and workbooks for all "natives" from the age of eight onwards. This system of forced work actually amounted to slavery (including physical punishment, rape and killings of "rebellious workers"). Africans appeared exclusively in terms of the Social Darwinist ideology and neither government nor white population doubted that the "fittest" held the right to oppress the "weak". ${ }^{27}$

The war in Southwest Africa generated much publicity in Germany. In 1906 the Social Democrats voted against further war credits (costs had amounted to almost 600 million Reichsmark) and Parliament was dissolved. The ensuing elections became known as Hottentotten-Wahlen ("hottentotts" being the derogatory name for the Nama). They ended in substantial losses for the SPD, since the country's conservative forces managed to present the colonial war as a cause that united all patriotic Germans and isolated those groups that questioned the colonialist practice. The publicity that went with the election campaign not only further established the racist ideology in German society, but also brought violations of the code of strict racial separation into focus.

The vast majority of the 12,000 German settlers in Southwest Africa was male. That relationships between them and African women were common consternated nationalists and race scientists. As early as 1896, the German Colonial Society began to finance the emigration of white women to the colony in order to stop the "bad habit of marriages between German men and hottentotts ${ }^{\prime 2}{ }^{28}$ African women were triply conspicuous, after all. They were members of the "opposite race", separated from the whites by such a wide gap that the only communication could be that between master and

\footnotetext{
25. Helmut Bley, Kolonialherrschaft und Sozialstruktur in Deutsch-Südwestafrika 1894-1914 (Hamburg, 1968), p. 205.

26. South Africa took over Southwest Africa as a mandate in 1920.

27. The attitude towards the inhabitants of the Pacific Island colonies was mellower; they were considered "distant cousins" (with the exception of the "Negroid" Papua New Guineans) and an eventual independence due to the cultural "uplifting" by the Germans was seen as a possibility. See Paul Rohrbach, Die Kolonie (Frankfurt a. M., 1907), pp. 100-102.
}

28. Deutsche Kolonialzeitung, 1896 , p. 197. 
servant. They were members of the opposite sex, incorporating all the aspects of female sexuality that white women were supposed to lack (or suppress), i. e. basically a wild, primitive, organic nature. And they belonged to a class that was associated with the animalistic.

The body was the site for these characteristics: early twentieth-century discourse reduced the black woman to her sexual organs. ${ }^{29}$ Their "monstrous size" proved her monstrous character. ${ }^{30}$ White women who violated the dogma of female sexual passivity, prostitutes and lesbians, were assumed to have those same physical abnormalities, but black women were abnormal per definition. Accordingly, the white attitude towards black women was extremely aggressive: they were portrayed as revolting, but at the same time assumed to be always sexually available. Their individuality did not have to be recognized; they were part of an interchangeable, anonymous black mass. Sexual contacts that reaffirmed this hierarchy were granted, marriages and long-term relationships were not. After all, the Social Darwinist equation of body and society meant that individuals had relevance not as such but only as members of the race. ${ }^{3 \mathrm{~T}}$ White settlers in mixed relationships therefore were "race traitors"; in fact they ceased to be proper members of the white race and degenerated to the level of their black partner. According to Southwest Africa's governor:

Not wife and offspring are raised to the level of the white husband and father, but the man is sinking to that of the woman. His house will not be the home of German ways and German family life, but he will squander and degenerate in his hut that will be dominated by the nature of the woman and that will, after initial resistance, lower the man to the sphere in which the woman is born and feels comfortable in. ${ }^{32}$

The biggest crime, though, was the production of mixed-race offspring that had access to the German nationality and could therefore irreversibly "pollute the nation's white blood". During the colonial war the authorities had already taken measures against miscegenation. From 1905 onwards all

29. Sometimes as literal as in the case of Sarah Bartmann from South Africa. After being publicly displayed in several European cities as an example of black females' pathological sexuality (symbolized by her enlarged buttocks), she died in I8I5. Her genitals were first scrutinized by several scientists and then donated to the Musée de l'homme in Paris, where they are still exhibited. See Paula Giddings, "The Last Taboo", p. 445.

30. A character, which had been established earlier. Hegel's description of man-eating African Amazons, a classical castration fantasy, is the only example he gives of African political systems, (Georg Friedrich Wilhelm Hegel, Vorlesungen, p. 142). White racism obviously also includes an obsession with the size of black male genitals, though they never became the topic of a similarly elaborate scientific discourse.

31. Or, as contemporary sociobiology puts it, as "carriers of genes".

32. Theodor Leutwein, Elf Jahre Gouverneur in Deutsch-Siudwestafrika (Berlin, 1908), p. 232. See also Albert Raibmayr, Inzucht und Vermischung beim Menschen (Leipzig, 1897), p. 51. 
marriages between whites and "natives" ${ }^{n 3}$ were declared illegal (including those already existing), mixed-raced children were denied access to schools $s^{34}$ and German men married to or living with African women were excluded from all German institutions in the colony, and could not vote, buy land or get financial support from the government. ${ }^{35}$ Social pressure in the colonial society thus resulted not in a loss of class status but in expulsion from a white community that included all classes.

All these measures aimed to prevent people of mixed ancestry legally becoming Germans, which would have both given them the right to acquire property in the colonies and to settle in Germany. Even more important were political rights like voting, which would have turned them from passive objects of German politics into active participants in the decision-making process. ${ }^{36}$ Actually, the vast majority of the children of white settlers and black women was illegitimate, and including them with the powerless "natives" posed no legal problem. Only the churches favored bringing up mixed-raced children in special institutions. Removed from their mothers' negative influence, missionaries believed, they could develop the qualities of their fathers' race that made them superior to "pure blacks", so that they later could be used as mediators between white rulers and black subjects. ${ }^{37}$

Despite confirming to the dominant ideas, the government's practice of generally treating non-white and German as exclusive categories violated German laws that did not forbid marriages on grounds of race and granted citizenship to wives and children of German men. In the wake of the war in Southwest Africa, race scientists and nationalist groups started a debate to end this unclear legal situation. They desired either changed laws or reasons to limit citizenship to "pure whites" within the existing system. For the most part, this debate took place in the conservative mainstream press, liberal or progressive papers hardly caring about the subject at all. The only dissenting voice thus came from the churches, but an outline of the debate shows that this dissent was quite ambiguous.

The principled social anthropologists held the first position. They did not mind how large - or small - the mixed-race population in the colonies

33. Colonial law for Southwest Africa defined each person as a "native" that had an African ancestor, however far removed. See: BAB, R IOoI, Bd. 54I8, pp. 364-379.

34. Accordingly, many settlers married to African women sent their children to Germany.

35. See: Evangelisches Zentralarchiv Berlin (EZB), 5/3016: Die deutsche evangelische Gemeinde in Windhuk, p. II7; "Stärkung des weissen Rassenbewußtseins", PAR 1906/7, p. 423. Between 1906 and 1908 similar laws were introduced in the other German colonies.

36. The image of the wicked, but smart mulatto who incites the passive "natives" to rebellion was very vivid in the German imagination. See PAR 1905/6, p. I12 and 469; 1906/7, p. 256.

37. At least three such institutions, limiting education to gardening and cooking, existed in Southwest Africa. See EZB, 5/3016, p. 99 and pp. 198-199. 
or Germany itself was, one drop of black blood was enough to poison the whole German nation. Miscegenation was a crime against nature and all sexual contacts between the races had to be outlawed. ${ }^{38}$ Accordingly, they favored a radical change of laws. ${ }^{39}$ The proponents of this most extreme position could use the authority of Germany's leading expert on "racial mixing", the anthropologist Eugen Fischer, who had stated:

If there is the probability, or even the mere possibility that bastard blood damages our race without the realistic chance that it will improve us, any absorption must be prevented. I take this to be so absolutely obvious, that I can consider any orher point of view only as that of complete biological ignorance [...] this is about the survival - I choose my words consciously - of our race, this has to be the main criterion, ethical and legal norms just have to be secondary to that. ${ }^{40}$

Those unconcerned with racial mixing as a matter of principle took a second, more pragmatic stand. Their interest lay in preventing any person of mixed ancestry from becoming a German national. Accordingly, they focused on the legitimate children of white settlers and black women, favoring an addition to German laws that would explicitly exclude those children. In 1908, the Colonial Society topped its list of recommendations to the government with the demands that "no colored can acquire the German nationality" and that "marriages between coloreds and whites in the colonies cannot be registered. Children of those marriages are considered coloreds. ${ }^{n t}$ At the same time, proponents of this position looked for ways of interpreting existing marriage laws in a manner that would achieve their aims, e.g. by claiming that no African could fulfill the legal marriage qualification of "mental sanity".42

Both the Catholic and the Protestant churches held a third position.

38. Indeed, the numbers were not quite in relation to the reactions. In 1909 , there were fifty "mixed marriages" and 4,284 "mulattos" registered in Southwest Africa. See Theodor Gentrup, Die Rassenmischehen in den deutschen Kolonien (Paderborn, 1914), p. 32.

39. Twenty-five years later, fascist laws introduced this change by severely punishing all sexual relations between "Aryans" and members of "foreign races".

40. Eugen Fischer, Die Rehobother Bastards und das Bastardisierungsproblem beim Menschen (Jena, 1913), p. 303, (italics in original). Fischer, who in the Weimar Republic became head of the Kaiser Wilhelm Institut, center for all eugenic and anthropological research, and who successfully continued his career under the National Socialists and in the federal republic, had built his reputation on publishing "the first scientific study" of racial mixing (conducted I908 in Southwest Africa). Using new methods, namely Mendel's laws, he came to the same old conclusions: "bastards" were inherently inferior, dangerous and unnatural. Interestingly enough, up to this day his work on racial mixing is considered groundbreaking.

41. "Bericht uber die Jahreshauptversammlung in Bremen, 12 Juni", Deutsche Kolonialzeitung (DKZ), (1908), p. 44I.

42. V. Fuchs, "Zur Frage der Mischehen zwischen Reichsangehörigen und Eingeborenen in Deutsch-Südwestafrika", $D K Z$, (1909), p. 38. See also: H. von Hoffmann, "Die Mischehenfrage", DKZ, (1909), p. 793 and J. Friedrich, "Die rechtliche Beurteilung der Mischehen nach deutschem Kolonialrecht", Koloniale Zeitschrift, (1909), p. $36 \mathrm{I}$. 
They vehemently opposed any restriction of marriage rights. Nevertheless, they too condemned interracial marriage and racial mixing. Their opposition mainly sprang from the fact that governors in the colonies had not only outlawed civil but also religious marriage ceremonies between whites and blacks. That was trespassing into a territory that the churches considered exclusively their own. Consequently, they were ready to compromise as long as they remained in control of religious ceremonies. In fact, they were quite eager to show that they principally agreed with the Social Darwinists:

Christian morality demands - our opponents might say - that the colored wives and mulatto children acquire the German nationality with all legal consequences, Christian morality wants to force the bastardization of the German nation! No, that is not the conclusion. Christianity simply demands that a possible relation between the white [man] and the colored woman should be legitimate, it does not judge on its legal position. Should the German government think it wise to refuse the colored elements entry into the community of citizens, Christianity will not protest. $^{43}$

In 1912, when the Secretary of Colonial Affairs sought legalization of segregationist policies in the colonies, the debate reached Parliament. Social Democrats and the catholic center party managed to pass a parliamentary measure that forbade marriage bans on grounds of race. While this appears quite progressive on the first look, it had no positive effect on colonial practice. Also, supporters of the measure unanimously condemned racial mixing and agreed to a limited citizenship for black Germans. One argued: "As long as the cultural development has not progressed in such a way that the natives are culturally equal to the Europeans, it is acceptable that they [children of mixed marriages] e.g. will have limited voting rights." ${ }^{\text {"4 }}$ All parties agreed that "German" and "white" belonged together. The law that the colonial secretary had introduced suggested that a small group of mixedraced persons should be considered German, whereas the rest forever lost the right to apply for membership in this category. First however, this privileged group had to be legally redefined as "white". Similarly, the opponents of marriage restrictions advocated full civil rights only for those "mulattos" who by looks and character somehow qualified as "white". Of course, this attitude required rather twisted thinking, but left the unity of nationality and race intact.

In practice, both the Secretary of Colonial Affairs, who had ended his speech against the measure with the exclamation: "We are Germans, we are whites and want to stay whites" ${ }^{45}$ and the governors of the colonies refused

43. Theodor Gentrup, Rassenmischehen, p. 90-91. See also Denkschrift des Ausschusses der deutschen evangelischen Missionen, 3 September 1912, p. 61.

44. MP Gröber of the Center-Party in Theodor Gentrup, Die Rassenmischehen, p. 42.

45. Ibid., p. 41-42. 
to act on the parliamentary decision, so that marriage bans kept on existing until Germany lost its colonies in the First World War.

This debate over "Germanness" likely influenced parliamentary discussions around the nationality law of 1913. Both cases show the triumph of biologist definitions of "German". The nationality law took pains to differentiate between citizens, i.e. persons of German nationality but not necessarily German ethnicity (as constructed by science), e.g. Poles in Prussia, and Germans, i.e. persons of "German blood" but not necessarily German nationality, e.g. Baltics. The latter category was seen as the more relevant, since identity was not built around a community of citizens, but around the community of "Germans". ${ }^{46}$ That this necessarily meant exclusion and division of the population according to scientifically-sanctified but highly questionable racial categories became increasingly obvious.

\section{THE CIVIL SOCIETY}

The end of the First World War brought about democracy in Germany and the Social Democrats gained control of the government for the first time. But this shift failed to transform society's attitude on race. In the first place, this attitude did not appear to be political; it rather stemmed from "scientific discoveries". In the new republic, with its numerous social reform movements and trust in (scientific) progress, Social Darwinism continued to gain influence. ${ }^{47}$ Accordingly, dominant ideas about races still relegated blacks to the bottom of German society.

The nationality law of 1913 did not deprive mixed raced children fathered by German men of German citizenship (even though that clearly meant something different than being German), but Africans from the former colonies living in Germany could not gain this status, instead they were handed "foreigners' passports", leaving them - and their families - in effect without nationality. ${ }^{8}$ Naturalization was theoretically possible, but German authorities assumed that Africans in general could not reach the required moral, educational and economic level. ${ }^{49}$ Of course, this was a self-fulfilling prophecy. Science had concluded that blacks, when living in a society with

46. See EZB, 5/340: Reichs- und Staatsangebörigkeitsgesetz, pp. 3, 7, 8 and 28.

47. An example of continuity in spite of political changes is the "Society for Racial Hygiene". Founded in 1905 as a politically and religiously neutral organization (only open to whites, though), by 1916 it included virtually all important biologists and anthropologists in its ranks. By 1920 lectures on racial hygiene were part of the curricula of all German universities and in 1926 the state-financed Kaiser Wilhelm Institut for anthropology began to co-ordinate all research in anthropology, biology and eugenics. See Peter Weingart et al., Rasse, Blut und Gene. Geschichte der Eugenik und Rassenhygiene in Deutschland (Frankfurt a. M., 1988).

48. A parliamentary motion to grant citizenship to children of German women married to stateless men (aimed at Danes in Northern Germany) failed out of concern that it would cover those mixed marriages. See BAB, R Ioor, 6r Kol DKG 1077/I, p. 230.

49. BAB, RKA- $4457 / 7$, p. 64 . 
whites, due to their genetic inferiority automatically formed the underclass. ${ }^{50}$ Therefore, their choice of work was restricted to what was considered appropriate for their race. An unusually high number of Africans in Germany had come to study, but the majority ended up as musicians, circus artists and manual workers. ${ }^{5 \mathrm{~A}} \mathrm{~A}$ fairly typical black German family history recalls:

My father, Kala King, was born in 1895 in Duala, Cameroon, which was a German colony then. He came to Germany before World War I [...]. He studied to become a teacher. His idea and that of the Germans was that he'd return to Cameroon after finishing his studies. But things turned out different: he met his wife and decided to stay in Germany. As an African, he couldn't work in his profession of course, no one would have given him a job as a teacher. So they decided to become Vaudeville-dancers. ${ }^{52}$

Moving to the men's home countries was not an option for interracial couples, either. German planters and companies, still largely in control of the excolonies' economies, strictly refused to employ Africans married to white women. ${ }^{33}$

In the colonial period already, it had become obvious that relationships between black men and white women were even more threatening to the white world order than the reverse case, which had dominated discussions in the IgIos. Central argument to the rejection of interracial contacts had been "the honor of the white woman". It was in danger when white men preferred black women, but more so, of course, when she was directly involved and in the worst case, actively. Imperial Germany was shaken by several scandals around relationships between white women and African men. The press reacted with great shock, especially because the women involved were from respectable middle class backgrounds. ${ }^{54}$

The Social Darwinist literature, of course, completely ignored the possibility of consensual relationships. It could not fathom this worst threat to the natural order - the white woman, mother of the race, betraying it, mating with black men and producing "bastards". Instead, the supposedly enormous sexual drive of black males, "naturally" directed towards unwilling white women, became the most popular argument for the necessity of the racial hierarchy. Half-hearted attempts at explaining this drive were secondary to describing its effects. Blacks had so long been characterized as

50. See e.g. Baur et al., Erblichkeitslehre und Rassenhygiene, p. 412.

51. See: Katharina Oguntoye, Eine afro-deutsche Geschichte. Zur Lebenssituation von Afrikanern und Afro-Deutschen in Deutschland von 1884 bis 1950 (Berlin, 1997), pp. 56-60.

52. Astrid Berger, "Sind Sie nicht froh, daß Sie immer hierbleiben dürfen?" in Katharina Oguntoye et al., Farbe bekennen. Afro-deutsche Frauen auf den Spuren ibrer Geschichte (Berlin, 1986), p. 115.

53. See BAB, R IOoI, 6I Kol DKG I077/I, p. 86.

54. See BAB, R rooI-1077/1, p. 219 and DKZ 1909, p. 593/4. As a consequence of the scandals the Ministry of Foreign Affairs prohibited the immensely popular public exhibitions of "natives". See Sander L. Gilman, "Black Sexuality and Modern Consciousness", in Rheinhold Grimm and Jost Hermand (eds), Blacks and German Culture (Madison, WI, 1986), p. 36. 
irrational, impulsive and overtly sensual, that it seemed only logical that they could not exercise the sexual restraint that was so central to contemporary Europeans. Therefore, permanent white male control was necessary to produce the ideal black male: childlike, subservient, asexual and non-threatening. Any divergence from this principle immediately evoked elaborate visions of the black beast, bent on raping white women and destroying the white race. The French occupation of the Rhineland in 1919 exposed the extent of this paranoia.

That part of Germany was controlled by the French "archenemy" was a visible and exploitable symbol of Germany's defeat. Of a much higher symbolic value, however, was the presence of several thousand Asian and African soldiers among the French troops. As soon as the peace talks began, the Social Democratic German government based its protests against the occupation, meant to last for fifteen years, on the presence of these troops. Subsequently, they became targets of a campaign against the "Black Horror on the Rhine" that was orchestrated by the government, financed by the industry and supported by all influential groups of society: political parties (only excepting the communists), churches, nationalist groups, women's organizations, professionals and scientists. The hysterical campaign, that had hundreds of thousands followers all over Europe and North and South America focused on the image of the "primitive African beast" that roamed around the streets of a civilized nation raping and killing: "Victims of the endless bestiality of the black monsters are found dead in fields and trenches, their clothes torn to pieces, some with bites that clearly show how the animal fell upon its pitiful victim. " $" 5$ The numerous propaganda material indulged in detailed descriptions of alleged acts of sexual violence, giving the campaign a pornographic tinge. This focus on the most powerful racist image succeeded in creating a racial solidarity that overcame deep national and political antagonisms. ${ }^{56}$ From an aggressor responsible for the first "world war", Germany was turned into a helpless victim of black aggression. ${ }^{57}$

There were marked differences to the discussions of the I9Ios, most notably rape in the earlier case had not been a topic, since the men involved were white and the victims black, but there were also crucial similarities. Again, despite the small number of mixed-race children, warnings against the "bastardization" of Germany abounded. And not only in propagandapamphlets, a medical journal asked: "Shall we silently endure that in future

55. Joseph Lang, Die Schwarze Schmach. Frankreichs Schande (Berlin, 1921), p. 8.

56. For an overview of the campaign and the decisive role e.g. the British socialists played in it see Robert C. Reinders, "Racialism on the Left: E.D. Morel and the 'Black Horror on the Rhine", International Review of Social History, 13 (1968), Pp. I-28.

57. An inquiry conducted by the British Foreign Office in 1920, that showed the unfoundedness of the accusations against the black soldiers, did not have any influence on the continuous propaganda. See ibid., p. Io. 
days not the light songs of white, beautiful, well-built, intelligent, agile, healthy Germans will ring on the shores of the Rhine, but the croaking sounds of greyish, low-browed, broad-muzzled, plump, bestial, syphilitic mulattos?" ${ }^{\text {s8 }}$ The massive reactions to several hundred black Germans among millions of white compatriots reveals the impact of the racist Social Darwinism: every single black German had a high symbolic value. To admit that one at the same time could be German and black had become impossible, since both terms were treated as contradictory racial categories. The systems' logic demanded that exceptions were impossible. Only within this line of thought does the genuine belief make sense that "in the long run this is about the survival or decline of the white race" ${ }^{n 9}$ Accordingly, black Germans and the relationships that produced them had to be defined as deviant, as consequences of an abnormal situation: "Those mulatto children are either products of violence or the white mother was a whore. In both cases there is not the least moral obligation to this racially foreign offspring [...]. ${ }^{n 60}$ They violated an idea of racial normality that was so crucial to the country's identity that it made more sense to adjust reality to ideology than the other way round:

May France and other countries handle their race matters as they please, for us there is only one thing: elimination of anything foreign, especially in those damages caused by brute violence and immorality [...]. Sterilization of all mulattos that the Black Horror on the Rhine left us! ${ }^{61}$

Since the children, usually referred to as "Rhinelandbastards", for the most part were born to unmarried German women within Germany, a Germany that was still under observation of the Allies, there could be no denial of citizenship. Also, contrary to the nationalist groups within Germany and supporters in other countries, the German government did its best to suppress the subject of mixed-race children, since research among the white mothers had shown that only one of them claimed to have been raped - a fact that was considered quite embarassing. ${ }^{62}$ Nevertheless, the government initiated lists of mixed-race children (not only those fathered by soldiers) and considered several solutions to the "problem". That the existence of black Germans did constitute a problem was beyond doubt for the authorities. The original idea of transferring all of them to Africa had to be given up, since Germany had lost its colonies and could not expect co-operation

58. Friedrich Rosenberger, Arztliche Rundschau, Nr. 47/1920, in Heinrich Distler, Das Deutsche Leid am Rhein. Ein Buch der Anklage gegen die Schandherrschaft des französischen Militarismus (Minden, 192I), p. 56.

59. Joseph Lang, Die Schwarze Schmach, p. I6.

6o. Hans Macco, Rassenprobleme im Dritten Reich (Berlin, 1933), p. 13-14.

61. Ibid., p. 16.

62. Reiner Pommerin, Sterilisierung der 'Rheinlandbastarde": Das Schicksal einer farbigen Deutschen Minderheit 1918-1937 (Düsseldorf, 1979), p. 23. 
from other colonial powers. The second plan of sterilizing them could not be put into practice since the necessary consent of the mothers could not be gained and it was feared that the Allies would not react favorably to such a measure. ${ }^{63}$

The National Socialists, gaining power in 1933, were not disturbed by such considerations. Using the existing lists and the enthusiastic support of the race scientists, forced sterilizations of several hundred black Germans began in 1937. According to fascist laws, they also lost their citizenship, the right to work, go to school or study and to own property, and an unknown number of them was sent to concentration camps. ${ }^{64}$

\section{“DON'T LOOK SO SAD, JUST BECAUSE YOU'RE A LITTLE NEGRO": BLACK GERMANS IN THE FEDERAL REPUBLIC ${ }^{65}$}

The second German democracy attempted to break with certain traditional structures that had proven fatal, but national identity was not among them. The citizenship law of the young republic was the same one that defined "Germanness" since 1913 in a restricted, biologist sense that showed no trace of jus soli aspects. Accordingly, the confusion of race/ethnicity and nationality that went with it remained; it was assumed that in the case of Germany the different categories were indeed one. This meant that the situation of those who violated the image of German ethnic uniformity did not change. Black Germans, who had lost their citizenship under National Socialism, had massive difficulties regaining it in the Federal Republic. One woman recalls:

I reapplied for German citizenship. And 1963 I got it, finally. They even asked me whether I had a voucher for losing it. What madness! I had to write a German essay to prove I could write without mistakes. My certificate of baptism and all other documents didn't count, I was treated like a foreigner. ${ }^{66}$

Since the existence of a population that was not white and still German was as unthinkable after 1945 as it was before, history was both ignored and repeated. The persecution of black Germans under fascism, the hysteria around the "Rhinelandbastards" and the anti-miscegenation laws miraculously vanished from public consciousness. At the same time, the old

63. Pommerin, Sterilisierung der "Rheinlandbastarde", pp. 94-95.

64. See Robert W. Kesting, "Forgotten Victims: Blacks in the Holocaust", The Journal of Negro History, 77 (1992), pp. 30-36.

65. In 1952, "Mach nicht so traurige Augen, weil du ein Negerlein bist" by Leila Negra, a black German teenager, was a Top-Ten hit song in Germany. See Gisela Fremgen, und wenn du dazu noch scharz bist. Berichte schwarzer Frauen in der Bundesrepublik (Bremen, 1984), p. no.

66. Anna G. und Frieda P., "Unser Vater war Kameruner, unsere Mutter Ostpreussin, wir sind Mulattinnen", in Oguntoye et al., Farbe bekennen, p. 81. 
positions continued to guide discussions about non-white Germans, this time under the heading "occupation children" (Besatzungskinder).

In I952, not only did "Don't Look So Sad" make the top of the German charts, but scientific "race studies" revived within the academy. Responsible was the former Kaiser Wilhelm Institut for anthropology, founded 1926 in the Weimar Republic, headed for sixteen years by an anthropologist who had built his reputation on "bastard studies" in the Kaiserreich, and reaching a peak of activity with fascism. ${ }^{67}$ It was one of the few German scientific centers that was not closed down by the Allies (it was renamed, though). Seven years after the end of the war, the institute published a study on mixed-raced children based on material gathered during the preparation of the forced sterilizations. It ended with the conclusion that "[e]specially the children's strong animalism will surely cause certain problems" ${ }^{68}$

Just as the unchanged nationality law revealed a consistent political attirude towards race matters, the work of the institute showed the consistency of the scientific positions. It is not much of a surprise, therefore, that public reactions to "racial mixing" did not change either. In the r950s black Germans once again were defined as unnatural, a product of extraordinary circumstances; the label "occupation children" targeted this. ${ }^{69}$ Again, the public viewed black soldiers foremost as potential rapists, white women in relationships with them as whores and their children as mistakes of nature. ${ }^{70}$ Again, removal of the children to a more appropriate surrounding, i.e. Africa or the US, was seen as the preferable solution. After all, as a 1952 parliamentary debate on the issue concluded, "the climate in this country does not suit them ${ }^{71}$ Continuing its colonial tradition, the Protestant church established at least one "mulatto village" to house black children in preparation

67. Apart from continued "bastard studies" and expertise on race, the Institute initiated Mengele's "experiments" in concentration camps. See Weingart et al., Rasse, Blut und Gene, pp. 399-423. 68. Walter Kirchner, "Untersuchung somatischer und psychischer Entwicklung bei EuropäerNeger-Mischlingen im Kleinkindalter unter Berücksichtigung der sozialen Verhältnisse", quoted in Benno Müller-Hill, Tödliche Wissenschaff, p. 115.

69. Of the 66,730 "occupation children" officially registered by the German authorities in 1955, i.e. children fathered by allied soldiers, 62,000 were white; public, scientific and political interest was focused exclusively on the black children, however. See Klaus Eyferth et al., Farbige Kinder in Deutschland und die Aufgaben ihrer Eingliederung (Munich, 1960), pp. 11-12.

70. Several studies conducted in the 1950s show the population's negative attitude towards "the niggerlovers' and their bastards", Luise Frankenstein, Uneheliche Kinder von auslandischen Soldaten mit besonderer Berücksichtigung der Mischlinge (Genf, 1953), p. 29; see also Eyferth et al., Farbige Kinder in Deutschland, pp. 74-78. Magazine articles and stories of the 1950s had a less aggressive attitude towards the children, rather portraying them as "tragic mulattos", but presented their fathers in "black horror" tradition as drunken, animal-like rapists. See Rosemarie K. Lester, "Blacks in Germany and German Blacks", in Grimm and Hermand, Blacks and German Culture, pp. 122I28.

71. See Fremgen, und wenn du dazu noch schwarz bist, p. 98. 
for their later emigration. But in spite of support by Albert Schweitzer and the NAACP, this did not prove a workable solution. ${ }^{72}$

While IQ tests showed no difference between black and white children, the vast majority of two hundred teachers of black students who had been surveyed agreed that "mulattos" were generally less intelligent. ${ }^{73}$ This belief was manifested in the extraordinary small number of black children recommended for higher education. ${ }^{74}$ Job recommendations for girls were restricted to washerwoman, chambermaid, factory worker or typist, for boys it was circus artist, musician, mechanic or elevator boy. ${ }^{75}$

When black children reached puberty, public interest focused again on the girls' sexuality. Numerous magazine articles dealt with topics such as "How colored girls seduce white men" or "Drama of a mulatto girl in Germany: she had to love them all ${ }^{p}{ }^{76}$ Far from being seen as part of the population, black German women embodied "exotic fun". But where serious relationships were concerned, the fun ended. Female and male black Germans were believed to have minimal chances of finding a (white) marriage partner; their existence was perceived as a mistake that should not be repeated. A contemporary study on mixed-race children concluded:

Racial mixing is almost exclusively seen as something negative, even threatening. Superstitious ideas, memorized as biological laws, are connected with it, e.g. that always the negative characteristics are transmitted, so that children of mixed relationships are mentally and physically inferior. Or it is said that it is never certain whether a parent looking relatively little Negroid might have a totally black child with kinky hair and thick lips [...]. Even though this fear of racial mixing is not justified, it has to be taken into consideration in the future. ${ }^{77}$

\section{CONCLUSION}

Attitudes towards interracial relationships in twentieth-century Germany were surprisingly consistent. Six decades and four different political systems did not change the fact that Germans perceived blacks - be they African, Afro-American or German - almost exclusively in terms of their alleged sexuality. Differentiation among class lines did not occur, since blacks automatically appeared as working-class. This brings into focus the similar stereotypes that were used in the discourses around the "lower races" and the "lower classes". Political groups as well as scientists, on the other hand, offered "race solidarity" as a means to overcome class conflict within the

72. Lester, "Blacks in Germany", p. 121.

73. Eyferth et al., Farbige Kinder in Deutschland, p. 8.

74. Ibid., p. 54 .

75. Ibid, p. 77.

76. Fremgen, und wenn du dazu nich schwarz bist, p. 65. See also Lester, "Blacks in Germany", pp. 128-130.

77. Eyferth et al., Farbige Kinder in Deutschland, p. I05. 
white society, deeming (biologically defined) class differences unimportant where the "war of races" was concerned. German publics judged sexual relationships between blacks and whites as immoral and unnatural, but the interaction of gender and race images led to a harsher reaction to relations between black men and white women. The fear and rejection of "racial mixing" and people of mixed ancestry, though, seemed less dependent on gender, the important factor here was to keep the German nation "white".

Racial construction assigned opposite mentalities to the races. Only whites were granted differentiated personalities and societies. This differentiation could include class and gender conflicts as internal problems, while the West saw conflicts around race as external, imposed by black outsiders who embodied everything whites were not (or should not be). Loss of "racial purity" was therefore equated with loss of identity. This idea required that the separation of races was presented as necessary and natural. The acceptance of a mixed raced population within the white West would have shown that cultural identity is not connected to "race". That this acceptance never took place shows that the West still depends on race to define itself. The massively negative reactions that relatively small numbers of interracial relationships and non-white Germans repeatedly invoked are an example of how central and deep-seated this racial definition is. Science's clinging to the validity of the race concept also reflects this. ${ }^{78}$ And references to "science" continue to justify racist exclusion, while "racist excesses" are condemned, but never analyzed within the context of this illusory concept of the pure white West. Without recognition of the historical construction of ideas about race, exclusionary policy continues to find ample justification, as the recent debates on German national identity have re-emphasized.

78. Be it in the form of sociobiology that holds positions similar to those of the social anthropologists and nevertheless receives favorable treatment in the mainstream press, as e.g. the reception of Murray's and Herrnstein's The Bell Curve shows; see Stephen Frazer, The Bell Curve Wars (New York, 1995). Or in the modified variation of "invincible cultural differences" between the "races", see Berrin Ozlem Otyakmaz, Auf allen Stühlen: Das Selbstverständnis junger türkischer Migrantinnen in Deutschland (Cologne, 1995). 